
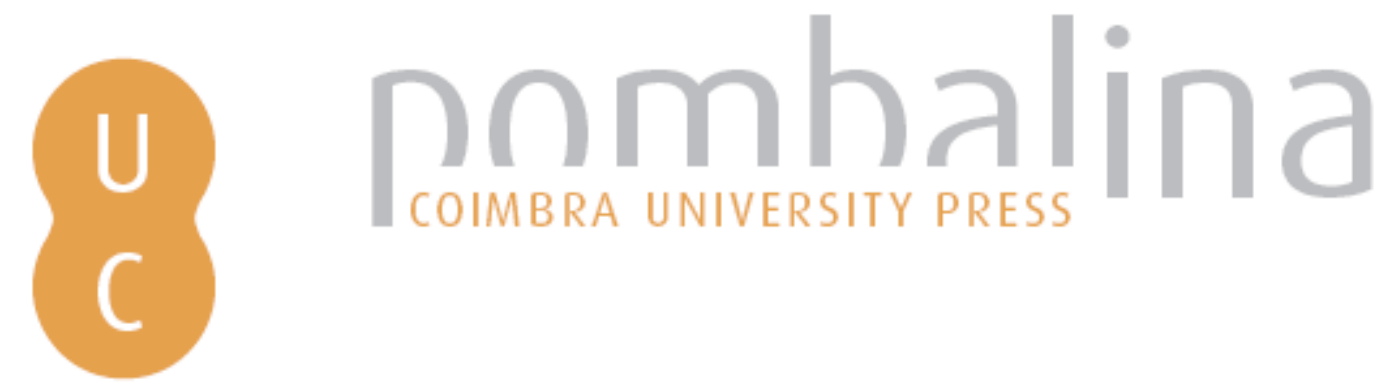

\title{
Zweckmässigkeit (conformidade a fins) e mecanicismo nos processos vitais: 0 Antagonismo entre Kant e Roux
}

\author{
Autor(es): $\quad$ Frezzatti Jr, Wilson Antonio \\ Publicado por: Imprensa da Universidade de Coimbra \\ URL \\ persistente: URI:http://hdl.handle.net/10316.2/38236 \\ DOI: $\quad$ DOI:http://dx.doi.org/10.14195/978-989-26-1049-8_2 \\ Accessed : $\quad$ 26-Apr-2023 15:32:13
}

A navegação consulta e descarregamento dos títulos inseridos nas Bibliotecas Digitais UC Digitalis, UC Pombalina e UC Impactum, pressupõem a aceitação plena e sem reservas dos Termos e Condições de Uso destas Bibliotecas Digitais, disponíveis em https://digitalis.uc.pt/pt-pt/termos.

Conforme exposto nos referidos Termos e Condições de Uso, o descarregamento de títulos de acesso restrito requer uma licença válida de autorização devendo o utilizador aceder ao(s) documento(s) a partir de um endereço de IP da instituição detentora da supramencionada licença.

Ao utilizador é apenas permitido o descarregamento para uso pessoal, pelo que o emprego do(s) título(s) descarregado(s) para outro fim, designadamente comercial, carece de autorização do respetivo autor ou editor da obra.

Na medida em que todas as obras da UC Digitalis se encontram protegidas pelo Código do Direito de Autor e Direitos Conexos e demais legislação aplicável, toda a cópia, parcial ou total, deste documento, nos casos em que é legalmente admitida, deverá conter ou fazer-se acompanhar por este aviso.

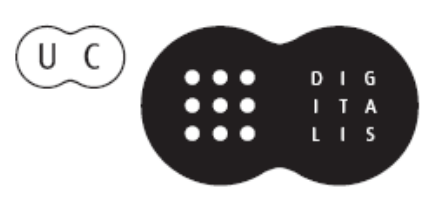



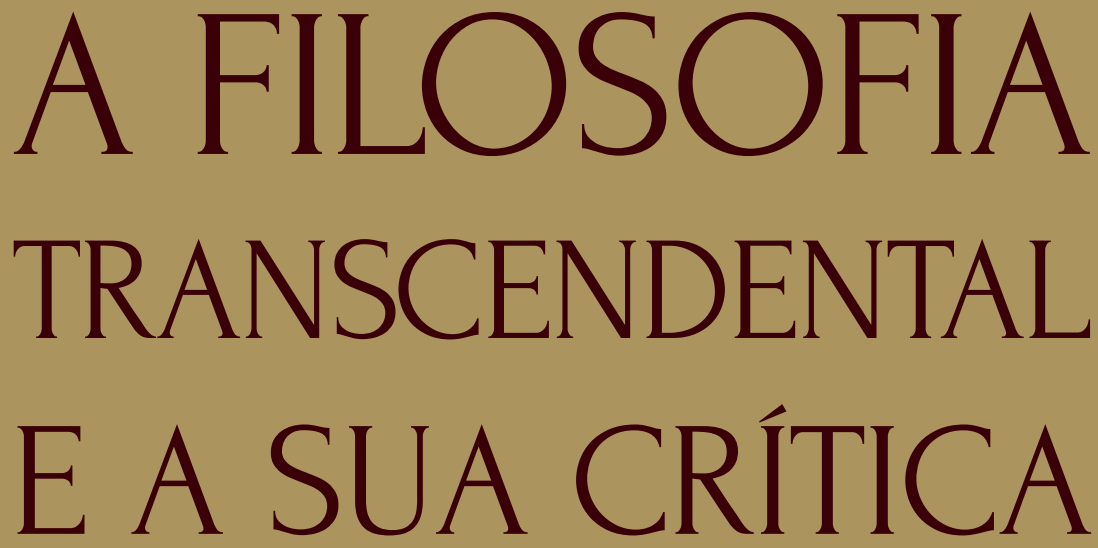

IDEALISMO • FenOMENOLOGIA • HERMENÊUTICA

\author{
DIOGO FERRER \\ LUCIANO UTTEICH \\ (COORDENADORES)
}




\title{
ZWECKMÄSSIGKEIT (CONFORMIDADE A FINS) E MECANICISMO NOS PROCESSOS VITAIS: O ANTAGONISMO ENTRE KANT E ROUX
}

ZWECKMÄSSIGKEIT AND MECHANICISM IN VITAL PROCESSES: THE ANTAGONISM BETWEEN KANT AND ROUX

Wilson Antonio Frezzatti Jr*

(UNIOESTE - Universidade Estadual do Oeste do Paraná)

\begin{abstract}
This Chapter proposes that the developmental mechanics (Entwicklungsmechanik) of the German biologist and embryologist Wilhelm Roux is antagonist to the Kantian concept of purposiveness (Zweckmässigkeit). Our research of Der Kampf der Theile im Organismus (1881), Kritik der Urteilsktaft (1790), and their concepts of organism shows that Roux does not solve certain problems answered by Kant, which favours that vitalist theories still flourish in the biological thought of the late nineteenth century.
\end{abstract}

Keywords: Kant; Life; Mechanicism; Organism; Purposiveness; Roux

*wfrezzatti@uol.com.br

Doutor em Filosofia pela Universidade de São Paulo (USP). Professor dos cursos de Graduação e Mestrado em Filosofia da Universidade Estadual do Oeste do Paraná (UNIOESTE). Professor colaborador do Mestrado em Filosofia da Universidade Estadual de Maringá (UEM). Coordenador do GT-Nietzsche (ANPOF). Membro do Grupo de Estudos Nietzsche (GEN-USP), do Groupe Internationale de Recherche sur Nietzsche (GIRN), e do Grupo de Pesquisa "Filosofia, Ciência e Natureza na Alemanha do século XIX" (UNIOESTE). 
Resumo: Este capítulo propõe que a mecânica do desenvolvimento (Entwicklungsmechanik) do biólogo e embriologista alemão Wilhelm Roux é antagonista ao conceito kantiano de finalidade ou de conformidade a fins (Zweckmässigkeit). Nossa investigação de A Luta das Partes no Organismo (1881), da Crítica da Faculdade do Juízo (1790) e de suas respectivas noções de organismo mostra que Roux não resolve algumas questões respondidas por Kant, o que propicia que teorias vitalistas ainda floresçam no pensamento biológico da segunda metade do século XIX.

Palavras-Chave: Conformidade a fins; Kant; Mecanicismo na Biologia; Organismo; Roux; Vida

O objetivo deste trabalho é apresentar o livro A Luta das Partes no Organismo (1881), do biólogo e embriologista alemão Wilhelm Roux, como antagonista à concepção kantiana de organismo e, consequentemente, ao conceito kantiano de finalidade ou de conformidade a fins (Zweckmässigkeit). Essa contraposição é feita por Roux através de uma teoria mecanicista do desenvolvimento embrionário e da diferenciação celular, a qual, acreditamos, não resolve algumas questões respondidas pelo filósofo de Königsberg, situação que mantém as portas abertas às alternativas vitalistas no pensamento biológico da segunda metade do século XIX.

Kant esteve desde o início envolvido de alguma forma com o pensamento sobre a vida, investigação que, na época do filósofo, não era objeto específico de nenhuma ciência, mas que, posteriormente, foi assumida pela disciplina chamada biologia ${ }^{59}$. O pensamento bio-

${ }^{59} \mathrm{Na}$ época em que Kant escreveu seus textos, a biologia ainda não havia se constituído enquanto uma disciplina científica, e o estudo dos seres vivos estava disperso entre o estudo da Terra, a medicina, a botânica, a história natural, etc. No início do século XIX, período em que os estudos sobre a evolução, a fisiologia, a bioquímica, 
lógico e o pensamento kantiano influenciaram-se reciprocamente: as ideias kantianas sobre o conhecimento abriram a possibilidade de uma nova filosofia da natureza, mas, ao mesmo tempo, as discussões biológicas contribuíram para formar o pensamento kantiano ${ }^{60}$. O trabalho crítico de Kant foi praticamente contemporâneo da constituição da biologia enquanto disciplina científica e foi importante para estabelecer algumas noções axiais, principalmente as de organismo e de conformidade a fins da natureza (Zweckmässigkeit der Natur). O período de final do século XVIII a início do século XIX marca uma acirrada disputa entre as explicações finalistas e as mecanicistas (causas eficientes) para se firmarem enquanto racionalidade dos fenômenos naturais. Por outro lado, o sistema filosófico kantiano parece ter seu desenvolvimento semelhante ao de um organismo vivo: desenvolve-se desde o interior (per intus susceptionem) e não por incrementos provenientes do exterior (per appositionem $)^{61}$. Esse sistema, tal como um organismo vivo, organiza-se por meio de uma ideia que só no fim se revela, sendo ela a responsável por toda a sua arquitetônica ${ }^{62}$.

\footnotetext{
a embriologia, a citologia e a histologia começaram a se desenvolver, surge o termo "biologia". A palavra, em seu sentido atual, parece ter sido criada em 1800 pelo médico alemão Karl Friedrich Burdach (cf. Mendelsohn (1964), 40). Gottfried Reinhold Treviranus, em Biologia ou Filosofia da Natureza Viva (Biologie, oder Philosophie der lebenden Natur, 1802), considera a biologia a ciência que unifica os seres vivos: "semelhança de aspecto no funcionamento desigual do mundo externo é o caráter distintivo da vida". Lamarck também foi responsável pela consolidação do termo, sendo que, também em 1802 , o utilizou para indicar a continuidade entre os mundos animal e vegetal e a necessidade de unificar os seus estudos. Podemos dizer que a biologia nasceu buscando definir a propriedade ou a qualidade que caracterizava os vários tipos de seres vivos.

60 Cf. Santos (2012), 18-20.

${ }^{61} \mathrm{Na}$ Crítica da Razão Pura (1787), em Doutrina transcendental do método, Capítulo III - Arquitetônica da razão pura, Kant declara: "O todo é portanto articulado (articulatio) e não amontoado (coacervatio), podendo, é verdade, crescer internamente (per intus susceptionem), mas não externamente (per appositionem), tal como acontece com um corpo animal cujo crescimento não leva à adição de um membro, mas antes, sem alterar a proporção torna cada um deles mais forte e mais eficiente para a sua finalidade" (Kant (1999), 492-493).
}

62 Cf. Santos (2012), 24. 


\section{Kant e a investigação acerca dos seres vivos}

Santos aponta algumas preocupações filosóficas de Kant acerca das questões biológicas ${ }^{63}$ : a) A redutibilidade dos princípios e das leis particulares da natureza à maior simplicidade e unidade possíveis: aspecto que aparece, por exemplo, nos ensaios sobre as raças humanas, no Apêndice à Dialética transcendental e na Introdução à Crítica da Faculdade do Juízo (CFJ), (Kritik der Urteilsktaft, 1790); b) A possibilidade de explicar a estrutura e a geração dos seres vivos pelas leis gerais do mecanicismo universal: caso o mecanicismo não dê conta dessa explicação, deve-se procurar e justificar um princípio transcendental que dê racionalidade aos seres orgânicos. Na segunda parte da terceira crítica, temos o princípio teleológico, pressuposto transcendental da Zweckmässigkeit der Natur e produto da faculdade de julgar reflexionante (reflektierende Urteilskraft). Além disso, como articular, num sistema superior de princípios, uma legalidade mecânica para a natureza em geral e uma finalística no caso especial dos seres vivos?; c) O estatuto epistêmico-transcendental da explicação finalista no estudo da natureza; d) A explicação da unidade do gênero humano e da diversidade de raças, a finalidade da espécie humana: essas preocupações constam principalmente nos ensaios de antropologia física; e) A necessidade ou não da intervenção de um poder supremo nos fenômenos naturais; e f) Como se inscreve a ordem teleológica da natureza na ordem teleológica dos seres morais: investigação de se há, na natureza, um supremo sentido final de ordem moral.

A obra de Kant, em sua relação com o pensamento biológico, é dividida, também por Santos, em três momentos ${ }^{64}$ : as primeiras abordagens biológicas (1755-1766); a abordagem antropológica sobre as raças humanas (1775-1788); e o interesse sobre temas biológicos no

${ }^{63}$ Cf. Santos (2012), 26-29.

${ }^{64}$ Cf. Santos (2012), 38-56. 
contexto da filosofia crítica. Em História Universal da Natureza e Teoria do Céu (Allgemeine Naturgeschichte und Theorie des Himmels, 1755), na qual há uma explicação mecânica para a formação do cosmos, o filósofo alemão já percebia a dificuldade de explicar a vida apenas mecanicamente. Perguntava-se, em O único Fundamento Possivel para uma Demonstração da Existência de Deus (Der einzige möglische Beweisgrund zu einer Demonstration des Daseins Gottes, 1763), se é possível reduzir todos os fenômenos naturais a uma única ordem necessária da natureza ou se haveria uma ordem contingente natural que exigiria um outro princípio para sua explicação. Nesse contexto, interessa-se pela discussão do desenvolvimento da vida entre pré-formacionismo e epigênese. Kant sempre defenderá a ideia de que o orgânico é irredutível ao mecânico ${ }^{65}$. Em seus ensaios de 1775, 1777, 1778 e 1788 sobre as raças humanas, o filósofo alemão propõe a noção de Naturgeschichte (história da natureza) em oposição a uma Naturbeschreibung (descrição da natureza), o que vai se desenvolver, em seus trabalhos posteriores, em uma teleologia de caráter transcendental para investigação dos organismos (o princípio de conformidade a fins). Assim, o transcendental vai resolver a incapacidade das teorias mecânicas da natureza para explicar a vida.

Nos textos da filosofia crítica, as concepções biológicas foram importantes para o estabelecimento da concepção transcendental kantiana. Na segunda edição da Crítica da Razão Pura (1787), Analítica transcendental § 27 ("Dedução transcendental dos conceitos puros do entendimento"), Kant faz uma analogia entre as teorias explicativas do conhecimento e dos fenômenos biológicos: o empirismo representa a geração material e mecânica dos conceitos, assim como o racionalismo inatista representa o sistema de pré-formação da razão pura, sendo

65 Em Sonhos de um Visionário Esclarecidos pelos Sonhos de um Metafísico (Träume eines Geisterseher, 1766), Kant afirma que a vida é dependente de um princípio imaterial, interno e autodeterminante, que é irredutível à matéria. 
que a filosofia crítica é o sistema da epigênese da razão pura ${ }^{66}$. Acima já apresentamos a comparação entre o organismo e a arquitetônica do sistema kantiano de conhecimento: deve haver um princípio de racionalidade que, análogo à epigênese, explique a própria razão, seus usos e seus limites ${ }^{67}$. Na filosofia teórica, temos a analogia entre o ser orgânico e razão; na filosofia da história, o desenvolvimento do plano da natureza em relação à espécie humana; e na filosofia moral, a investigação de se o aspecto prático da razão é abarcado pelo plano da natureza, possibilitando a realização da plena destinação do homem ${ }^{68}$.

Kant estabeleceu um importante debate com o naturalista alemão Johann Georg Forster ${ }^{69}$ :

“Talvez não tivéssemos a terceira Crítica como a temos hoje, com a sua Segunda Parte dedicada à Crítica do Juízo

\footnotetext{
66 Adiante trataremos da disputa entre epigênese e pré-formacionismo e de sua importância para Kant.

${ }^{67}$ Há ainda metáforas biológicas em Prolegômenos a toda metafísica futura, Ideia para uma História universal numa intenção cosmopolita e Fundamentação da metafísica dos costumes.

68 Não devemos ficar com a ideia de que há uma relação especial entre a biologia e a filosofia kantiana. Santos ((2012), 56) adverte que há, na obra kantiana, analogias também com a química, a astronomia, a geografia, o direito, etc. Sobre a química, podemos apresentar o trabalho de Lequan, que assevera: "A química, longe de ser marginal ou periférica, desempenha um papel decisivo na obra de Kant. Se Kant aborda frequentemente essa disciplina de maneira oblíqua e por ocasião de outras reflexões, ele a trata também por ela mesma enquanto ciência. A química, em sua filosofia, tem um duplo estatuto: ela é simultaneamente uma metáfora, uma analogia, até mesmo um paradigma que descreve o método do filósofo crítico, e um objeto de reflexão para a filosofia da natureza, sendo a química um ramo da física" (Lequan (2000), 5) (tradução de nossa responsabilidade). A química forneceria a Kant não só o modelo de reações de síntese, que consiste em unir intimamente duas matérias heterogêneas numa terceira distinta das duas primeiras, processo análogo à síntese que ocorre entre duas faculdades do conhecimento humano (sensibilidade e entendimento), mas também forneceria o modelo do método de análise, ou seja, de separação e purificação, análogo ao procedimento de distinguir o puro do empírico, os númenos dos fenômenos. Kant teria trazido da química os conceitos de "afinidade" e "interssuscepção", e também o problema da origem da diversidade da matéria. A abordagem química de Kant teria influenciado filósofos da natureza, tais como Schelling e Hegel, fornecendo uma justificação metafísica para o dinamismo (cf. Laquan (2012), 5-8).

${ }^{69}$ Forster participou da segunda viagem do inglês James Cook ao Pacífico (1772-1775), quando realizou importantes pesquisas etnológicas sobre os polinésios.
} 
Teleológico, se não fossem as observações críticas de Forster aos ensaios de Kant sobre as raças humanas."70

As críticas de Forster estimularam o filósofo alemão a desenvolver melhor suas ideias e pressupostos. Kant, segundo o naturalista, construiu frágeis teses acerca das raças humanas, apoiado em fontes pouco confiáveis e em débeis informações empíricas, o que teria resultado na subversão dos conceitos e dos métodos consolidados da história natural $^{71}$. O debate tem seu foco na questão das bases epistêmicas e metodológicas dessa disciplina, na contraposição entre o empírico e o teórico, ou seja, do ponto de vista kantiano, na contraposição entre a Naturbeschreibung e a Naturgeschichte. Da perspectiva kantiana, a primeira nada mais é que uma mera classificação por semelhança de características externas enquanto a segunda busca estabelecer um Sistema da Natureza para uso do entendimento, isto é, uma rede de transformações que a Terra e os seres vivos sofreram e que produz relações entre eles. A garantia desse uso pelo entendimento apoia-se num princípio transcendental, no princípio de inteligibilidade da natureza ou teleológico. Assim, as críticas de Forster parecem ter impulsionado Kant a desenvolver mais claramente um princípio que orientasse a pesquisa e a observação do naturalista da Naturgeschichte: os seres vivos e sua atividade são pensados como fins da natureza, noção que parece ter sido tomada de empréstimo da racionalidade do mundo moral.

Muito importante para Kant também foi sua ligação com o zoólogo alemão Johann Friedrich Blumenbach ${ }^{72}$. O filósofo alemão, que o influenciou com sua filosofia, tinha em boa consideração as ideias do

70 Santos (2012), 59.

${ }^{71}$ Cf. Santos (2012), 59-66.

72 Cf. Santos (2012), 50-58. Por meio de estudos de anatomia comparada, Blumenbach propôs a existência de cinco raças humanas: caucasiana, mongólica, malaia, etíope e americana. 
zoólogo: além do problema das raças, tinham em comum a questão do desenvolvimento orgânico.

\section{Pré-formacionismo x Epigênese}

Uma importante discussão biológica na época de Kant era sobre o desenvolvimento dos seres vivos: a disputa entre epigenistas e pré-formacionistas, ou, sob outra perspectiva, entre finalistas e mecanicistas. Debate no qual o biólogo Wilhelm Roux também participou. De modo geral, o mecanicismo estava ao lado de um pré-formacionismo, e o vitalismo finalista, aliado a um epigenismo. Dizemos de modo geral, pois neste tema as definições exatas e distintas tendem a recair em equívocos e simplificar extremamente o processo histórico ${ }^{73}$. O pré-formacionismo propunha que os seres vivos existiam pré-formados e embutidos no interior de seus antepassados, como um jogo de bonecas russas (Matrioshka), postos por Deus no início da Criação, sendo que cada um teria seu momento adequado de se manifestar. No século XVII, esse modo de pensar não se opunha francamente ao mecanicismo e estava de acordo com as ideias cartesianas da potencialmente infinita divisibilidade da res extensa e da criação do mundo por um deus relojoeiro ${ }^{74}$. Como pré-formacionistas, podemos citar: Nicolas Malebranche, Jan Swammerdam, Paracelso, Charles Bonnet e Lazzaro

73 Acompanhamos Lenoir ((1982), IX) quando afirma que considera dogma pensar que um pesquisador ou era vitalista ou era mecanicista e que os defensores da teleologia eram necessariamente vitalistas. Segundo o autor, a questão central nesse debate era a causalidade nos seres vivos. Outra visão tradicional rechaçada por Lenoir, e também por nós, é aquela que acredita que a Naturphilosophie teria sido a única influência filosófica dos biólogos alemães do século XIX: Kant também manteve um diálogo profícuo com os biólogos. Apesar de semelhanças em outras concepções, há diferenças fundamentais entre a noção de teleologia kantiana e a da Naturphilosophie (cf. Lenoir (1982), 3-4). Há ainda que considerarmos, na segunda metade do século XIX, a influência dos textos de Darwin.

${ }^{74}$ Cf. Pinto-Correia (1999), 28. 
Spallanzani. Em 1759, o biólogo alemão Caspar Friedrich Wolff publica sua tese de doutorado, Theoria Generationis, um trabalho com embriões de galinha que demonstrava a formação de órgãos sem a relação com estruturas pré-formadas ${ }^{75}$. Wolff acreditava que o desenvolvimento do embrião ocorria por uma força invisível inerente à matéria viva: a vis essentialis ou essentliche Kraft. Assim, o pensamento epigenista dispensava a participação de forças mecânicas. Como epigenistas, podemos citar: William Harvey, Karl Ernst von Baer e Christian Pander. O debate era bem acirrado, já que a epigênese funcionava melhor na explicação das variações e das observações empíricas do desenvolvimento embrionário dos órgãos, e a pré-formação explicava melhor a continuidade entre gerações. Esse impasse propiciou o surgimento de teorias conciliatórias, como a de Kant e a de Blumenbach: o organismo possui o Bildungstrieb (impulso de formação), transmitido por meio das células embrionárias, mas há também a participação de forças mecânicas, como veremos adiante ${ }^{76}$.

Haveria, segundo Lenoir (1982), na biologia alemã do século XIX, um programa de pesquisa que tinha como meta a unificação dos modelos de explicação teleológico e mecanicista. E Kant é o referencial teórico desse programa, não influenciando apenas Blumenbach, mas também os estudantes deste e os de Georg Christoph Lichtenberg na Universidade de Göttingen, além de Treviranus, Carl Friedrich Kielmeyer, Johann F. Meckel, von Baer, Johannes Müller, Carl Bergmann e Rudolph Leukart, entre outros ${ }^{77}$. Os biólogos alemães da primeira década do século XIX, de modo geral, basearam-se fortemente em concepções de forças vitais emergentes, tal como a Bildungstrieb de Blumenbach, e, no final da década de 1840, ganham corpo as interpretações descritas em termos de relações funcionais num contexto fisiológico. Essa mudança ocorre,

\footnotetext{
75 Cf. Pinto-Correia (1999), 29.

76 Sobre as posições epigenistas de Kant e sua dubiedade, cf. Marques (2012).

77 Cf. Lenoir (1982), 17-53.
} 
segundo Lenoir ${ }^{78}$, devido aos avanços na física da energia, na química e na fisiologia, mas, em grande medida, também pelo programa de pesquisa que Kant e Blumenbach ajudaram a construir ${ }^{79}$. O filósofo de Königsberg, por meio principalmente da Crítica da Faculdade do Juízo (1790), dá as bases para que Blumenbach, Johann C. Reil e Kielmeyer produzam uma primeira abordagem teleomecanicista. Esse programa vai ser desenvolvido por Meckel, von Baer, Heinrich Rathk, Johannes Müller, Hermann Lotze, Justus Liebig, Bergmann e Leuckart. A noção de teleologia de Kant não é antropomórfica, nem transcendente ou religiosa, mas resultante das questões da causalidade na biologia e, podemos dizer, das limitações das explicações mecanicistas sobre os seres vivos ${ }^{80}$.

Em Sobre o Impulso de Formação e Atividade de Geração (Über den Bildungstrieb und das Zeugungsgeschäfte, 1781), apoiado principalmente em seus experimentos com celenterados, Blumenbach considera que o impulso de formação é a causa primária de toda geração, reprodução e nutrição, e não pode ser reduzida aos constituintes químicos. Como propriedade emergente, o Bildungstrieb não existe para além dos constituintes materiais, tendo um caráter teleológico imanente, o que afasta esse conceito tanto do vitalismo como do mecanicismo extremados ${ }^{81}$. O impulso de formação poderia também explicar a adaptabilidade dos seres vivos ao ambiente (adaptação funcional), sendo capaz de sustentar um Sistema da Natureza.

78 Cf. Lenoir (1982), 12-15.

${ }^{79}$ Lenoir $((1982), 12)$ chama esse programa de pesquisa de teleomecanicismo. Para designar a ideia que o princípio vital não existe independente da matéria viva, mas é uma propriedade emergente da relação entre as partes, o autor utiliza o termo "materialismo vitalista", criado pelo historiador da medicina Oswei Temkin (cf. Lenoir (1982), 4). Sobre o materialismo vitalista, cf. Lenoir (1982), 17-53.

80 Sobre os tipos de teleologia na biologia, cf. Lenoir (1982), 9-12 e Mayr (1998), 65-69. Esses tipos ocupam várias posições entre o vitalismo e o reducionismo extremos, e, de modo geral, buscam garantir o caráter próprio dos fenômenos biológicos contra o reducionismo físico-químico.

${ }^{81}$ Cf. Lenoir (1982), 20-24. 
Foi Kant quem chamou atenção para o papel centralizador do Bildungstrieb de Blumenbach numa teoria geral da organização animal. A maior contribuição de Kant a Blumenbach foi explicitar o modelo cognitivo que o naturalista sugeria nas entrelinhas ${ }^{82}$. Esse papel centralizador tem o mesmo sentido de "princípio regulativo" no pensamento kantiano sobre o conhecimento: ocorre uma analogia entre o organismo vivo e a organização epistemológica, sendo que, nesta última, temos a postulação de um âmbito transcendental, não dogmático nem empírico ${ }^{83}$.

\section{A Zweckmässigkeit na Crítica da Faculdade do Juízo de Kant}

Os modelos mecânicos sozinhos não dão conta de explicar os seres orgânicos, pois, no reino da vida, é impossível pensar a causa sem seu efeito e vice-versa, há uma interdependência entre elas. Em Kant, a conformidade a fins (Zweckmässigkeit) assume o papel de uma causa final e as partes só podem ser pensadas em relação ao todo. A natureza kantiana deve ser pensada como se (als ob) fosse um sistema de fins, e os seres orgânicos são pensados como se fossem fins que a natureza mesma se propõe.

Kant desenvolve essas ideias na Crítica da Faculdade do Juízo. ${ }^{84}$ A Urteilskraft é apresentada por Kant no texto de várias maneiras,

\footnotetext{
${ }^{82}$ Cf. Lenoir (1982), 23.

${ }^{83}$ Numa carta a Blumenbach com uma cópia da Kritik der Urteilskraft, datada de agosto de 1790, Kant afirma: "Seus trabalhos ensinaram-me muitas coisas. Na verdade, sua recente unificação dos dois princípios, a saber, o físico-mecânico e o teleológico, os quais todos pensavam, de modo contrário, serem incompatíveis, tem uma relação muito estreita com as ideias que atualmente me ocupam, mas que requerem exatamente o tipo de base fatual que você fornece" (apud Lenoir (1982), 24).

84 Para Cordeiro, no Apêndice à Dialética transcendental da Crítica da Razão Pura, já se encontram elementos teóricos importantes para a terceira Crítica, especialmente à antinomia da faculdade do juízo teleológico. Assim, não haveria um verdadeiro conflito entre o princípio da causalidade natural enquanto um princípio subjetivo ou regulativo e a primeira Crítica (cf. Cordeiro (2012), 1). A função regulativa (sistematizante) do princípio de causalidade mecânica na Crítica da Faculdade do Juízo não anula a função
} 
como, por exemplo: uma faculdade que, na ordem das faculdades do conhecimento, "constitui um termo médio entre o entendimento e a razão" 85; "faculdade de pensar o particular como contido no universal" 86; faculdade "da subsunção da intuição empírica (se o objeto é um produto natural) sob o conceito" 87 . Ao subsumir aspectos particulares dados pela experiência em regras gerais, a faculdade do juízo pode produzir a regra geral de dois $\operatorname{modos}^{88}$ : a) a regra pode ser dada a priori e é constitutiva e objetiva (constitui a natureza): faculdade do juízo determinante (bestimmende Urteilskraft); b) a regra geral é apenas sugerida por meio dos particulares e é regulativa e subjetiva (uso racional que produz uma unidade sistemática da experiência, cuja meta é guiar a investigação dos dados empíricos. Seus resultados não devem ser considerados como realidade objetiva): faculdade do juízo reflexiva (reflectierende Urteilskraft) ${ }^{89}$. No primeiro caso, a lei ou a regra necessária é indicada a priori pelo entendimento, e não há necessidade da faculdade do juízo determinante pensá-la. No entanto, a faculdade do juízo reflexiva deve dar a regra ou a lei a si mesma, pois deve subordinar a multiplicidade empírica (no nosso caso, os seres vivos) a uma unidade. E, para fazer isso, necessita de um princípio que não pode ser extraído da experiência, ou seja, deve ser um princípio transcendental ${ }^{90}$. Esse princípio torna possível um

constitutiva (determinante) da experiência, exercida pelo princípio da causalidade natural na primeira Crítica.

${ }^{85}$ Kant (2008), 12; CFJ, Prólogo à primeira edição. As citações da Crítica da faculdade do juízo seguem a tradução de Valério Rohden e António Marques (cf. Kant (2008)).

${ }^{86}$ Kant (2008), 23; CFJ, Introdução: IV - Da faculdade do juízo como uma faculdade legislante $a$ priori.

${ }^{87}$ Kant (2008), 248; CFJ, Segunda Parte: Crítica da faculdade de juízo teleológica (II Pt), Segunda Divisão: Dialética da faculdade de juízo teleológica (Div 2), § 77 Da especificidade do entendimento humano, pelo qual nos é possível o conceito de um fim natural.

88 Cf. Kant (2008), 23-25; CFJ, Introdução: IV.

${ }^{89}$ Não levaremos em consideração, neste trabalho, a faculdade de juízo reflexiva estética.

90 "Um princípio transcendental é aquele pelo qual é representada a priori a condição universal, sob a qual apenas as coisas podem ser objetos do nosso conhecimento em 
sistema de experiência segundo leis da natureza particulares, e ele não é determinado objetivamente, já que esse juízo reflete, não constitui. Em outras palavras, essa faculdade dá lei apenas a ela própria e não à natureza. Para Kant, esse princípio só pode ser a conformidade a fins ou finalidade (Zweckmässigkeit) ${ }^{91}$ :

"A natureza é representada por esse conceito, como se um entendimento contivesse o fundamento da unidade do múltiplo das suas leis empíricas [...] [pode-se] somente utilizar esse conceito, para refletir sobre eles [os produtos da natureza] no respeitante à conexão dos fenômenos na natureza, conexão que é dada segundo leis empíricas." 92

Como a faculdade do juízo reflexiva utiliza leis como um princípio de reflexão sobre objetos, princípio que ela dá a si própria, devendo buscá-las na experiência, essa dependência empírica das leis particulares promove a produção de uma diversidade de máximas (princípios subjetivos). Assim, entre elas, pode surgir um conflito e, consequentemente, uma antinomia. E, nessa antinomia, pode-se fundar uma dialética, chamada por Kant dialética natural ${ }^{93}$.

geral" (Kant (2008), 25; CFJ, Introdução: V - O princípio da conformidade a fins formal da natureza é um princípio transcendental da faculdade do juízo).

${ }^{91}$ Santos ((2012), 68-69) faz notar que o princípio transcendental da Zweckmässigkeit é aplicado em vários sentidos: meramente formal e subjetivo (apreciação estética das formas belas da natureza); objetivo e formal (entidades geométricas); material e objetivo (seres organizados da natureza, que só podem ser pensados como se fossem fins da natureza).

92 Kant (2008), 25; CFJ, Introdução: IV. Embora não possa ser conhecida a priori, isto é, seja contingente para nossa compreensão, a suposição da unidade dos seres orgânicos por meio do princípio da teleologia é necessária, pois "de outro modo não existiria qualquer articulação completa de conhecimentos empíricos para um todo da experiência na medida em que na verdade as leis da natureza universais sugerem uma tal articulação entre as coisas segundo o seu gênero" (Kant (2008), 27; CFJ, Introdução: V).

93 Cf. Kant (2008), 227-228; CFJ, II Pt, Div 2, § 69 - O que é uma antinomia da faculdade do juízo. 
“Mas no que respeita às leis particulares que nos podem ser dadas através da experiência, pode nelas existir uma tão grande multiplicidade e heterogeneidade que a faculdade do juízo deve servir-se dela própria como princípio, nem que seja para procurar uma lei nos fenômenos da natureza e observá-la, já que necessita de um tal fio condutor, mesmo que somente deva esperar um conhecimento de experiência interligado, segundo uma conformidade geral a leis da natureza, por conseguinte a unidade da mesma segundo leis empíricas." 94

Na multiplicidade das leis particulares, em relação aos seres vivos, Kant identifica duas possibilidades de unidades que formam essa antinomia, representadas por duas máximas, uma delas (a tese) é dada a priori pelo entendimento, e a outra surge através de experiências particulares $^{95}$. Na forma dialética, temos:

- A primeira máxima, a tese (Satz): “Toda geração das coisas materiais e das respectivas formas tem que ser ajuizada como possível segundo simples leis mecânicas";

- A segunda máxima, a antítese (Gegensatz): “Alguns produtos da natureza material não podem ser ajuizados como possíveis segundo leis simplesmente mecânicas (o seu ajuizamento exige uma lei completamente diferente da causalidade, nomeadamente a das causas finais)".

Tese e antítese não são determinantes, mas guiam a investigação biológica e, de certo modo, cumprem tarefas complementares nessa investigação ${ }^{96}$. Apesar dessa complementariedade e do caráter heurísti-

\footnotetext{
${ }^{94}$ Kant (2008), 228; CFJ, II Pt, Div 2, § 70 - Representação desta antinomia.

95 Para a discussão sobre o sentido dessa antinomia, cf. Cordeiro (2010).

96 Cf. Cordeiro (2010), 160.
} 
co e indeterminado do princípio teleológico, o filósofo alemão indica uma precedência do princípio teleológico sobre o princípio mecânico:

"O direito de procurar um tipo de explicação simplesmente mecânico de todos os produtos da natureza é em si completamente ilimitado. Mas a faculdade de apenas assim o conseguirmos é, segundo a constituição do nosso entendimento, na medida em que se ocupa de coisas como fins naturais, não só muito limitada, mas também claramente delimitada [begrenzt]." 97

As explicações mecanicistas são delimitadas, porque não dão conta dos fins naturais, o que faz com que os ajuizamentos dos seres vivos devam ter, simultaneamente às considerações mecanicistas, uma consideração teleológica ${ }^{98}$.

"Quando, por exemplo, mencionamos a anatomia de um pássaro, o oco de seus ossos, a posição das asas com vistas ao voo e da cauda para a direção etc., dizemos, sem termos que recorrer ainda a um tipo especial de causalidade, isto é, à dos fins (nexus finalis), que tudo isto é altamente contingente segundo o mero nexus efectious na natureza." 99

Ou seja, em termos estritamente mecânicos, o pássaro poderia ter se configurado de inúmeros modos diferentes sem formar uma unidade

${ }^{97}$ Kant (2008), 258; CFJ, II Pt, Apêndice: Doutrina do método da faculdade do juízo teleológica (Ap), § 80 - Da necessária subordinação do princípio do mecanicismo ao princípio teleológico na explicação de uma coisa como fim da natureza.

98 Por outro lado, não podemos, de nenhum modo, demonstrar a impossibilidade da produção de produtos naturais organizados através das relações mecânicas, pois, do mesmo modo, não somos capazes de compreender a infinita multiplicidade das leis particulares da natureza em seu fundamento interno.

${ }^{99}$ Kant (2008), 203-204; CFJ, II Pt, § 61 - Da conformidade a fins objetiva da natureza. 
viva. É o princípio teleológico que dá unidade ao ser vivo. Para nosso intelecto, para nós como seres humanos, é impossível reduzir os fins da natureza às relações mecânicas:

“Na verdade para isso seria necessária uma outra intuição, diferente da sensível, e um conhecimento determinado do substrato inteligível da natureza, do qual pudesse ser dado um fundamento do mecanismo dos fenômenos segundo leis particulares, coisa que ultrapassa completamente toda a nossa faculdade." 100

O princípio mecanicista, portanto, deve ser sempre subordinado a um princípio teleológico. O conceito de Zweckmässigkeit é uma ideia, isto é, um conceito por meio do qual a razão se esforça para pensar o todo dos seres organizados ${ }^{101}$. O uso lícito, ou seja, crítico, desse conceito somente ocorre como um princípio regulativo da faculdade do juízo: devemos pensar a conformidade a fins como uma realidade dada, como se ( $a l s ~ o b$ ) houvesse uma teleologia, uma destinação prévia nos seres vivos. Podemos observar a conformidade a fins na natureza, mas, devido ao seu papel de lei geral, ele não deve ser fundamentado na experiência, deve ter um caráter a priori:

“Este princípio [do ajuizamento da conformidade a fins interna em seres organizados], segundo o modo como ocorre, é dedutível da experiência, nomeadamente daquela que é metodicamente estabelecida e que se chama observação [Beobachtung]. Mas por causa da universalidade e da necessidade que esse princípio afirma de uma tal conformidade a fins, não pode simplesmente assentar na experiência, mas pelo contrário tem como

100 Kant (2008), 203-204; CFJ, II Pt, § 61.

101 Cf. Cordeiro (2010), 155. 
fundamento algum princípio a priori qualquer, ainda que seja meramente regulativo e aqueles fins existissem somente na ideia daquele que ajuíza e em nenhuma outra causa eficiente." ${ }^{102}$

O homem só pode pensar adequadamente os seres vivos considerando a causa final, a causa eficiente não é suficiente. Pensamos o mundo inorgânico mediante o entendimento como um encadeamento causal que vai apenas num sentido, no qual os efeitos pressupõem causas que não podem ser, ao mesmo tempo, efeitos delas próprias ${ }^{103}$. No entanto, um produto natural associado a um fim natural deve se comportar em relação a si mesmo reciprocamente como causa e efeito. E isso exige necessariamente que as partes, segundo sua existência e sua forma, somente sejam possíveis devido a sua relação com o todo. Essas duas exigências (as partes serem reciprocamente causa e efeito e elas se unirem formando uma unidade) possibilitam que pensemos um produto natural contendo "em si mesmo e na sua necessidade interna uma relação a fins, isto é, ser somente possível como fim natural e sem a causalidade dos conceitos de seres racionais fora dela" ${ }^{\prime 104}$. Em Crítica da faculdade do juízo $\S 66$, o filósofo alemão afirma que o princípio do ajuizamento conforme a fins é, ao mesmo tempo, a definição dos seres organizados105: "um produto organizado da natureza é aquele em que tudo é fim e reciprocamente meio"106. Nada é em vão no ser vivo, nada pode ser atribuído a um mecanismo natural cego.

102 Kant (2008), 218-219; CFJ, II Pt, Primeira Divisão: Analítica da faculdade de juízo teleológica (Div 1), § 66 - Do princípio do ajuizamento da conformidade a fins interna em seres organizados.

103 Cf. Kant (2008), 215; CFJ, II Pt, Div 1, § 65 - As coisas como fins naturais são seres organizados.

104 Kant (2008), p. 215; CFJ, II Pt, Div 1, § 65.

105 Kant, na Crítica da faculdade do juízo, utiliza apenas o termo "seres organizados" (organisierten Wesen). A palavra "organismo" (Organismus) aparece no Opus postumum (1799-1803) (cf. Santos (2012), 70).

106 Kant (2008), 218; CFJ, II Pt, Div 1, § 66. 
O ser organizado pode ser visto como uma máquina ou como um produto constituído por relações mecânicas, mas ele não é só isso. Num relógio, por exemplo, uma parte movimenta outras partes, mas não é causa eficiente de sua produção: “uma parte [no relógio] existe na verdade em função de outra, mas não é através [durch] dessa outra que ela existe"107. O relógio possui apenas força motora (bewegende Kraft), mas o ser vivo, além dela, possui força formadora (bildende Kraft), que forma e organiza sua própria matéria viva e que não pode ser reduzida a forças mecânicas. Dessa forma, o organismo também ultrapassa o produto artístico, pois este necessita de um ser racional exterior para ser formado, enquanto o ser vivo depende dele próprio, e seus produtos são organizados segundo um mesmo modelo108.

A faculdade do juízo reflexiva, para pensar a conexão manifesta das coisas vivas, deve utilizar uma causalidade diferente do mecanicismo, isto é, uma causalidade inteligente segundo fins, mas que não pode ser considerada determinante ou objetiva ${ }^{109}$. Esse aspecto aponta para a resolução da antinomia entre mecanicismo e teleologia:

“Toda a aparência de uma antinomia entre as máximas da autêntica forma de explicação física (mecânica) e da teleológica (técnica) repousa assim na confusão de um princípio da faculdade de juízo reflexiva com o da determinante, e da autonomia da primeira (que possui validade meramente subjetiva para nosso uso da razão a respeito das leis particulares

107 Kant (2008), 216; CFJ, II Pt, Div 1, § 65.

108 Não desenvolveremos aqui a relação entre Deus e o mundo. Segundo Santos ((2012), 73), Kant mantém um irredutível dualismo entre matéria e vida, pressupondo um supremo artista inteligente, distinto da matéria e da própria natureza, que originariamente deu à natureza material a capacidade de se auto-organizar e, num nível mais elevado, a capacidade de produzir seres organizados como se fossem fins que ela mesma se propõe. Assim, Kant evita o mecanicismo absoluto e o finalismo objetivo, salvando a autonomia do homem frente à natureza.

109 Cf. Kant (2008), 230-231; CFJ, II Pt, Div 2, § 71 - Preparação para a resolução da antinomia mencionada. 
da experiência) com a heteronomia da outra, a qual se tem que orientar segundo as leis (universais ou particulares) dadas pelo entendimento." 110

A aparente antinomia, como diz Cordeiro ${ }^{111}$, deve ser entendida no nível epistemológico, já que, no nível ontológico, as máximas se tornam efetivamente contraditórias. O uso não crítico ou dogmático do "como se" dessas máximas acarreta a transformação dos princípios subjetivos da faculdade do juízo em princípios constitutivos: trocamos o nosso modo de acesso aos objetos pelos próprios objetos. No uso dogmático, tanto a explicação mecanicista quanto a teleológica falham no conhecimento dos seres vivos. Como a realidade objetiva do princípio de conformidade a fins não pode ser provada, devemos seguir o caminho crítico, usando o princípio de modo transcendental: conceber os seres orgânicos como fins naturais ${ }^{112}$. É justificável por meio de princípios transcendentais, segundo Kant, uma conformidade a fins subjetiva nas suas leis particulares ${ }^{113}$. Isso significa que há possibilidade da conexão das experiências particulares dos seres vivos num Sistema da Natureza, conexão realizada pelo conceito de Zweckmässigkeit.

\section{O estatuto do conhecimento acerca dos seres vivos em Kant}

A unidade transcendental não implica objetivamente na unidade empírica. Assim, é um absurdo esperar que um Newton surja e

110 Kant (2008), p. 231; CFJ, II Pt, Div 2, § 71.

111 Cf. Cordeiro (2010), 164-170.

112 Cf. Kant (2008), 231-242; CFJ, II Pt, Div 2, § 72-75. Santos ((2012), 78) expressa essa situação da seguinte forma: "A vida e os seres orgânicos só podem ser compreendidos de alguma maneira, se supusermos um princípio não material na sua origem, o que só pode ser pensado por analogia com o modo humano de representar e realizar uma atividade orientada a fins".

113 Cf. Kant (2008), 203; CFJ, II Pt, § 61. 
explique, por meio das leis mecânicas e matemáticas da natureza, qualquer fenômeno biológico, por menor que seja ${ }^{114}$. Em consequência, o conhecimento biológico não pode ser reduzido aos princípios físicos. O que ultrapassa os fenômenos físico-químicos (mecânicos) nos organismos não pode ser constituído a priori. É por isso que se deve unir criticamente as explicações mecanicistas e teleológicas sobre os seres vivos ${ }^{115}$. Enfim, o caráter da biologia deve ser diferente daquele da física. Não temos, por exemplo, um juízo a priori para o conceito de espécie, o qual é definido como o conjunto dos indivíduos que se reproduzem entre si. Essa definição é empírica (reprodução) e não transcendental, o que exemplifica a necessidade de buscar as leis da biologia empiricamente.

É pela conformidade a fins que a nossa faculdade do juízo pode abordar de modo científico os seres vivos. Esse conceito, no entanto, não pode ser garantido a priori. Não há como garantirmos que os seres vivos em si tenham um princípio teleológico, que a conformidade a fins seja objetiva:

"contudo, o ajuizamento teleológico pode, ao menos de uma forma problemática, ser usado corretamente na investigação da natureza; mas somente para submeter a princípios de observação e da investigação da natureza segundo a analogia com a causalidade segundo fins, sem por isso pretender explicá-lo através daqueles." 116

A explicação, portanto, só pode ocorrer na causalidade mecânica, pois explicação implica uma dedução (Deduktion) que, no pensamento

114 Cf. Kant (2008), 241; CFJ, II Pt, Div 1, § 75 - O conceito de uma conformidade a fins objetiva da natureza é um princípio crítico da razão para a faculdade de juízo reflexiva.

115 Cf. Lenoir (1982), 29-32.

116 Kant (2008), 204; CFJ, II Pt, § 61. 
kantiano, significa uma legitimação do juízo ou justificação da pretensão de uma validade universal necessária ${ }^{117}$. Por sua vez, o princípio da conformidade a fins não pode ser usado para explicar, ele é apenas um conceito mais geral que apenas indica ou mostra a unificação de elementos empíricos ${ }^{118}$.

\section{A mecânica do desenvolvimento de Wilhelm Roux}

Pretendemos, neste trabalho, inserir o biólogo Wilhelm Roux ${ }^{119}$ no debate teleológico-mecânico na Alemanha do século XIX, confrontando-o diretamente contra a proposta kantiana. Vamos posicioná-lo no que Kant poderia chamar "mecanicismo dogmático", já que o biólogo alemão prescinde da noção de finalidade, especialmente de uma finalidade intrínseca, lançando mão apenas de relações mecânicas para explicar os fenômenos vitais. Roux, portanto, pretende fundamentar a biologia em bases diversas das kantianas, sendo que seu fio condutor apoia-se nas observações empíricas e não no transcendental.

117 Cf. Kant (2008), 126; CFJ, Primeira Parte: Crítica da faculdade de juízo estética, Dedução dos juízos estéticos puros, $§ 30$ - A dedução dos juízos estéticos sobre os objetos da natureza não pode ser dirigida àquilo que nesta chamamos de sublime, mas somente ao belo.

118 Cf. Kant (2008), 252; CFJ, II Pt, Div 2, § 78 - Da união do princípio do mecanismo universal da matéria com o teleológico na técnica da natureza.

119 O biólogo alemão Wilhelm Roux (1850-1924) formou-se em medicina na Universidade de Iena (1877), onde teve como professores Rudolf Virchow, Ernst Haeckel e Gustav Schwalbe. Trabalhou como professor na Universidade de Breslau (1879), na Universidade de Innsbruck (1889) e na Universidade de Halle (1895). Foi pioneiro na embriologia experimental e fundador da teoria da mecânica do desenvolvimento (Entwicklungsmechanik). Propôs também a teoria do mosaico da epigênese: após poucas gerações, as células embrionárias já desempenhariam papéis diferenciados. Em 1894, funda o primeiro periódico de embriologia experimental: Archiv für Entwicklungsmechanik der Organismen, existente até os dias de hoje com outro nome. Seus principais livros são: A Luta das Partes no Organismo (Der Kampf der Teile im Organismus, 1881); Sobre a Mecânica do Desenvolvimento dos Organismos (Über die Entwicklungsmechanik der Organismen, 1890); A Mecânica do Desenvolvimento (Die Entwicklungsmechanik, 1905); Terminologia da Mecânica do Desenvolvimento (Terminologie der Entwicklungsmechanik, 1912). 
O trabalho do biólogo alemão se insere no intenso debate do século XIX sobre os mecanismos da hereditariedade e do desenvolvimento embrionário, e invocava a ação de tropismos e tactismos (atração entre células por fatores químicos) para explicar a especialização das células, além de agentes exteriores tais como calor, luz, eletricidade e gravidade. Na mecânica do desenvolvimento de Roux, a luta entre as partes e a adaptação funcional são axiais e constituem as noções principais de A Luta das Partes no Organismo. O título completo do livro é A Luta das Partes no Organismo: Uma Contribuição ao Complemento da Doutrina Mecânica da Conformidade a Fins (Der Kampf der Theile im Organismus: ein Beitrag zur Vervollständigung der mechanischen Zweckmässigkeitlehre), o que já deixa explícito o objetivo de abordar o problema a partir da questão da conformidade a fins e um debate com a posição kantiana. No início do primeiro capítulo (I. A adaptação funcional: A. As realizações), Roux afirma que compreender a conformidade a fins (Zweckmässigkeit) na natureza é uma das mais antigas preocupações dos filósofos ${ }^{120}$. Empédocles teria sido o primeiro a descobrir o fim último de uma doutrina da conformidade a fins: a ação apenas de razões puramente mecânicas, ou seja, do movimento. Com isso, segundo Roux, o filósofo grego teria mostrado filosoficamente ser possível uma explicação mecânica dos organismos animais. O biólogo alemão define o que entende por conformidade a fins:

"A conformidade a fins [Zweckmässigkeit] não é intencional, mas um vir-a-ser, não é teleológica, mas uma história natural, originando-se de maneira mecânica; pois ela não corresponde a um fim [Zweck] pré-estabelecido, mas àquilo que possui qualidades necessárias para subsistir diante de certas

120 Cf. Roux (1881), 1-4. 
circunstâncias e permanecer. Somente nesse sentido falamos a seguir de conformidade a fins."121

No entanto, conforme Roux, a doutrina de Empédocles, que não era puramente filosófica, mas também propriamente científica e podia sustentar uma explicação empírica, ficou esquecida durante séculos. Charles Darwin e Alfred Russel Wallace redescobriram essa doutrina e propuseram a luta como a causa primeira do surgimento mecânico da conformidade a fins. A teoria da evolução mostra que as espécies se originam por diferenciações progressivas e que os organismos superiores descendem dos inferiores, porém poucas pesquisas trataram das causas e do modo de surgimento da conformidade a fins interna. Em outras palavras, a teoria da evolução não teria ainda sido aplicada ao indivíduo isolado, não sabemos se ela pode definir todas as conformidades a fins internas como consequências necessárias de princípios mecânicos. O objetivo de A luta das partes é, portanto, mostrar que a teoria da evolução de sua época não realiza esse propósito, e que, embora a luta pela existência darwiniana seja puramente mecânica, faltariam ainda outros princípio mecânicos ${ }^{122}$. Faltaria também uma explicação mecânica para o princípio de uso e desuso de Lamarck.

${ }^{121}$ Roux (1881), 2; grifos no original. As traduções do texto de Roux são de nossa autoria.

122 O livro A Luta entre as Partes no Organismo passou despercebido em sua época, não recebeu nenhuma citação significativa, não fez escola e não possuía protocolos experimentais (cf. Heams (2012), 11-15). Schwalbe considerou que a obra tinha um teor filosófico, num sentido pejorativo, sendo inadequada a um anatomista. Haeckel apenas felicitou Roux pela publicação. August Weismann teria sido o único biólogo de renome a se interessar pela obra. Mais importante, mas também sem repercussão: Darwin, pouco antes de morrer, escreveu numa carta a G. J. Romanes: "Mesmo que eu possa julgá-la imperfeitamente, trata-se da obra sobre evolução mais importante que já apareceu" (apud Heams (2012), 15-16). O esquecimento de Roux teria se dado pelo caráter pré-genético de sua teoria e por seus equívocos teóricos: sua teoria da embriogênese e sua teoria da divisão desigual dos cromossomos. Esta última ficou conhecida como teoria Weismann-Roux e foi refutada por Hans Driesch. Roux não aparece nenhuma vez no clássico texto de Lenoir (1982) sobre a discussão da teleologia na Alemanha do século XIX. Talvez o livro tivesse sido mesmo esquecido, se não fosse pelo impacto que causou no filósofo Friedrich Nietzsche* (cf. Heams (2012), 20-23). Entretanto, ainda segundo 
A formação do organismo, na teoria de Roux, é resultado do processo de adaptação funcional: a atividade incrementada aumenta a força específica de uma estrutura, enquanto que a diminuição da atividade causa atrofia $^{123}$. O mecanismo da adaptação funcional de Roux é o seguinte: a) Assim que uma excitação ou fator externo favorece a assimilação de uma substância qualquer, a célula tem sua composição e seu funcionamento alterados; b) A resposta à excitação constitui uma função e a própria excitação passa a ser necessária para a vida da célula (excitação funcional); c) O funcionamento da célula, do tecido ou do órgão torna-se, assim, a causa que determina o seu grau de desenvolvimento e a sua forma. Um exemplo: as trabéculas ósseas são estruturas organizadas de forma a suportar o melhor possível os esforços dos ossos. Essas estruturas não puderam ser produzidas por seleção natural, pois esta não pode produzir o desenvolvimento de uma estrutura útil além do necessário. A excitação funcional do osso é a ação mecânica, em cuja direção a nutrição se faz mais ativa. Os órgãos passivos regulam sua forma e estrutura segundo a direção do maior esforço que têm que suportar. Os órgãos ativos (os músculos, por exemplo) desenvolvem-se em razão direta da intensidade do seu funcionamento.

Heams (cf. (2012), 23-25), algumas intuições da obra mostram-se válidas atualmente, principalmente aquelas que desafiam as visões "genocentristas", como, por exemplo, as de Richard Dawkins. Além disso, algumas das noções do livro estariam de acordo com pesquisas atuais sobre imunologia e redes neurais.

$\left({ }^{*}\right)$ Nietzsche leu atentamente o livro em 1881 e 1883 . Sobre a influência de Roux no pensamento do filósofo alemão, cf. Müller-Lauter (1998) e Frezzatti (2001), 68-81 e 124-128.

${ }^{123}$ Cf. Roux (1881), 6-63. Essa ideia é derivada do princípio lamarckista da formação do órgão pela função, o que se costumou chamar lei do uso e desuso ou Primeiro Princípio de Lamarck. A alteração física ocorre porque a mudança do meio externo exige uma nova necessidade (besoin): fluidos e forças corporais são mobilizados para modificar a estrutura que irá satisfazer a necessidade (cf. Lamarck (1994), 216). Esse movimento corporal é o que Lamarck chama sentimento interior (sentiment intérieur). Por também se basear em conceitos darwinianos, como a luta pela existência e a seleção natural, Roux foi classificado como neolamarckista. Adaptação funcional (functionelle Anpassung) é o termo que Roux utiliza para se referir aos efeitos do uso e desuso (Wirkungen des Gebrauches und Nichtgebrauches), pois o considera mais geral (cf. Roux (1881), 6). 
A excitação funcional, para Roux, explica o aparecimento de estruturas que outras teorias atribuem à simples hereditariedade ou não conseguem explicar (como a teoria da seleção natural e, por consequência, da luta entre indivíduos). O tempo de uma existência individual não é suficiente para produzir um órgão: são necessárias inúmeras gerações para os efeitos do funcionamento do órgão se acumular. Contudo, esse acúmulo só é possível se as modificações devidas à excitação funcional forem transmitidas aos descendentes. Por outro lado, a excitação funcional permite que o ser vivo ultrapasse sua capacidade hereditária: uma simples função animal, a nutrição, é por si mesmo criadora - desencadeando a luta no interior do organismo, prepara o caminho para o surgimento de outras espécies. Essa explicação, o que é muito importante, exclui argumentos teleológicos: Roux utiliza-se de uma autorregulação interna que promove a formação do organismo ${ }^{124}$.

A adaptação funcional é explicada por meio de relações mecânicas. A alteração de estruturas e funções biológicas ocorre por meio da luta entre as partes constituintes do organismo: moléculas, células, tecidos e órgãos. A luta das partes orgânicas ocorre em quatro fases (Stufen): 1. Luta das moléculas orgânicas pelo espaço ${ }^{125}$ : O protoplasma da célula é formado por diferentes moléculas químicas. O líquido nutritivo (um fator externo) que envolve a célula favorece mais a

124 Esse aspecto da adaptação funcional foi ressaltada, no início do século XX, por Ernst Heinrich Haeckel (cf. Haeckel (1904), 302-305). A adaptação funcional explicaria a transmissão das características adquiridas durante a vida do indivíduo, o que para August Weismann seria impossível. A teoria do plasma germinativo de Weismann separa a célula em duas partes: o plasma germinativo (responsável pela transmissão de características aos descendentes e que não era identificado com o núcleo celular) e o somatoplasma (o restante da célula). As novas características adquiridas pelo somatoplasma durante a vida do organismo não seriam transferidas para o plasma germinativo e, por consequência, não seriam herdadas pela descendência. O plasma germinativo era descendente direto das células da geração precedente, não sendo, portanto, produto do organismo atual. Essa posição diferenciada do plasma germinativo levou Haeckel a acusar Weismann de ter reintroduzido a metafísica na biologia.

125 Cf. Roux (1881), 73-88. 
assimilação de determinadas moléculas. Haverá dentro da célula, conforme o meio em que estiver imersa, a preponderância de uma determinada substância. Da mesma maneira, agentes físicos e químicos favorecem ou dificultam a assimilação de determinadas substâncias de acordo com a sensibilidade destas à ação desses agentes. Como o espaço intracelular é limitado, produz-se entre as moléculas uma competição: aquela que for preponderante definirá o tipo da célula. A preponderância de certas substâncias, diferentes segundo a localização e o estado inicial da célula, é, portanto, a causa primordial da diferenciação ontogenética; 2 . Luta entre células ${ }^{126}$ : Da mesma forma que as moléculas, as células também reagem diferentemente aos fatores externos e ocupam um espaço limitado (no caso, o organismo). Aquelas mais capazes de se multiplicar, por se nutrirem mais rápido, tornam-se predominantes sobre as vizinhas. Entre as células constituídas pelas mesmas substâncias, aquelas com predominância mais forte multiplicar-se-ão mais. Através da reprodução, a diferenciação no nível superior, ou seja, nos tecidos, acentua-se; 3. Luta entre tecidos ${ }^{127}$; e 4 . Luta entre órgãos ${ }^{128}$ : A luta entre tecidos e órgãos prossegue do mesmo modo que entre as células, mas aqui certos limites são postos pelas exigências do organismo como um todo: uma predominância muito forte de certos tecidos ou de certos órgãos pode ser nociva e eliminar o organismo pela seleção natural (tumores e obesidade, por exemplo, que exaurem toda a alimentação e invadem o espaço dos outros tecidos). A luta entre as partes de Roux é um processo mecânico originado na assimilação de moléculas pelas células, o que assegura uma constituição totalmente aleatória das estruturas. É um processo cego, o que seria inadmissível para Kant na formação do organismo.

\footnotetext{
126 Cf. Roux (1881), 88-96.

127 Cf. Roux (1881), 96-102.

128 Cf. Roux (1881), 103-106.
} 
A mecânica do desenvolvimento, apresentada acima de forma sucinta, vai dar base à reflexão de Roux sobre o caráter específico da vida e do ser orgânico, tema abordado no quinto e último capítulo de A Luta das Partes (Da essência do organismo, Über das Wesen des Organismen) e que é o foco de nosso interesse neste trabalho.

\section{A essência do orgânico segundo Roux}

Apesar do desenvolvimento do conhecimento científico no século XIX, Roux considera que ainda não se sabe com clareza a verdadeira essência dos seres vivos ${ }^{129}$. O biólogo alemão aponta a definição de Aristóteles como uma das melhores ${ }^{130}$ : um complexo de instrumentos (organon, Werkzeuge), cada um responsável por determinada função. No entanto, com a descoberta dos seres vivos desprovidos de órgãos, que apresentam em seu protoplasma uma substância homogênea ${ }^{131}$, os naturalistas perceberam que a definição aristotélica não abrangia a essência da vida, mas apenas a característica principal dos organismos superiores. Os filósofos muito antes abandonaram a definição, já que utilizam a noção de alma para dar unidade ao corpo.

Antes de apresentar sua proposta, Roux afasta aquilo que não pode aceitar: "Essa essência não pode ser a ligação que une as diferentes partes para formar um todo, pois existem seres vivos desprovidos

${ }^{129}$ Cf. Roux (1881), 210-211. Verdadeira essência ou essência em Roux tem o sentido daquela característica ou qualidade (Eigenschaft) que diferencia os seres orgânicos dos demais seres naturais, isto é, daquilo que é próprio de todos os seres vivos.

130 Roux, em A luta das partes, não faz nenhuma citação direta de Kant, seja de seu nome, seja de seus textos. Embora por vezes utilize-se de termos kantianos, eles estão desvinculados das teorias kantianas. É o caso adiante dos termos "tempo", "espaço" e "apriorístico".

131 Roux refere-se aos seres unicelulares. Lembrar que, nessa época, a microscopia incipiente ainda não permitia visualizar as organelas celulares. 
de partes"132. As funções psíquicas também não podem ser aceitas como essência, pois não haveria nenhuma razão válida para pensar que as plantas e animais inferiores possuem consciência. O ser-para-si (Für-Sich-Sein) também deve ser rejeitado: é uma propriedade que não existe, sendo resultado apenas das relações internas em face do exterior. Aqui já temos um indício de que a essência do orgânico para Roux não pode ser um princípio anterior e separado dos próprios processos vitais. São ainda afastadas propriedades que também ocorrem na matéria inorgânica, ou seja, que são funções gerais de toda matéria e de todos acontecimentos (Geschehen) ${ }^{133}$, como é o caso da memória mecânica, da absorção, da conversão de forças, da composição química, entre outros ${ }^{134}$.

As propriedades acima mencionadas são consideradas "apriorísticas", pois são gerais, e como não resolveram o problema da essência dos seres vivos, Roux pretende investigar o que chama de "comportamentos espaciais e temporais"135. Como comportamento espacial, ou seja, que se refere à propagação (Ausbreitung) do orgânico, Roux investiga o crescimento (Wachstum) e a reprodução (Fortpflanzung) ${ }^{136}$. A reprodução é um caso especial do crescimento, e ambos procedimentos são a expressão quantitativa e são dependentes da assimilação

132 Como podemos inferir de suas considerações sobre os seres unicelulares, Roux parece utilizar o termo Organischen (orgânico) como sinônimo de ser vivo, deslocando o sentido tradicional de articulação de partes.

133 Roux prefere utilizar a palavra Geschehen (acontecimentos) ao invés de Erscheinung (fenômeno), mesmo quando a qualifica como orgânico, vital, biológico, etc.

${ }^{134}$ Cf. Roux (1881), 211-213. A memória mecânica é o efeito que subsiste à causa: trata-se de um caso particular da lei de inércia. O que Roux chama "força" é hoje melhor entendido como "energia"; assim, as teorias que consideram a força vital como resultado da transformação de forças físicas são também rejeitadas (conversão de energia). No caso da composição química, além dos compostos orgânicos não diferirem qualitativamente dos inorgânicos, a composição química das células vegetais e animais é diferente.

135 “Deixemos agora o exame do comportamento [Verhalten] dos processos orgânicos nas qualidades apriorísticas [aprioristichen Eigenschaften] de todos acontecimentos, e discutamos os comportamentos espacial e temporal" (Roux (1881), 213).

136 Cf. Roux (1881), 213-214. 
(Assimilation). Essas qualidades, no entanto, por si só, ainda não são suficientes para serem consideradas essenciais aos seres orgânicos. Os cristais, por exemplo, também crescem. Há necessidade de uma abordagem temporal ${ }^{137}$.

Os processos orgânicos parecem ser caracterizados por uma duração ininterrupta desde seu aparecimento. Embora a duração ou permanência também ocorra nos acontecimentos não orgânicos, tais como a erosão eólica e o movimento das marés, há uma diferença essencial: a continuidade dos processos inorgânicos tem uma dependência estrita das condições exteriores, se estas cessam, o processo cessa se não há vento, não há erosão -; os processos orgânicos têm uma dependência também das condições interiores. Em outras palavras, o processo vital continua apesar da variação das condições externas, ou ainda, o processo vital traz em si próprio a causa de sua conservação:

“Nada está isolado no mundo, muito menos o organismo, que tem que continuamente absorver e transformar a matéria do mundo exterior. Quanto mais complicado for o acontecimento, mais difícil será a conservação da constância." 138

O problema de Roux agora passa a ser encontrar quais as qualidades ou as características que propiciam essa permanência apesar da mudança das condições externas: essas qualidades formam a essência dos seres vivos. Para isso, constrói uma relação de qualidades que possuem uma hierarquia entre $\mathrm{si}^{139}$. A qualidade necessária (nothwendige Eigenschaft) é justamente o que diferencia os seres vivos dos outros seres naturais: como vimos acima, é a capacidade de permanecer, mesmo com a variação das condições exteriores. Ela

\footnotetext{
137 Cf. Roux (1881), 215-216.

138 Roux (1881), 70.

139 Cf. Roux (1881), 216-229 e 239-240.
} 
se realiza através da qualidade fundamental (Grundeigenschaft) do orgânico: a capacidade de autoformação dos elementos necessários à conservação em face das variações exteriores. A autoformação, por sua vez, realiza-se por meio de uma primeira qualidade específica (Specialeigenschaft), a assimilação, perpetuada por inúmeros mecanismos de autorregulação (Selbstregulation), e por meio da segunda qualidade específica, a supercompensação do que é consumido. "A autorregulação e a supercompensação, portanto, são as qualidades fundamentais e as necessárias condições prévias à vida"140. Elas são processos internos que garantem a capacidade do organismo permanecer em face da mudança das condições externas. Essas qualidades são necessárias para que outras sejam adquiridas, tais como a capacidade de contratibilidade (Fähigkeit der Contractilität), a configuração a partir de processos químicos (Gestaltung aus chemischen Processen), a ação reflexa (Reflexthätigkeit) e a sensibilidade (Sensibilität).

A assimilação é a capacidade (Fähigkeit) de se apropriar qualitativamente do que é estranho ao organismo e transformá-lo no que é próprio ou necessário: "a essência [Wesen] dessa capacidade é um tipo de autoprodução, de autoformação do necessário"141. Ao lado da assimilação, há outra exigência [Erfordernis] geral da essência do orgânico: a supercompensação do que é consumido (Übercompensation des Verbrauches). Ela envolve assimilar mais do que se consome, utilizar tudo que é consumido para manter sua duração e eliminar aquilo que não utiliza, devolvendo matéria ao ambiente. Enquanto o inorgânico só permanece dependendo exclusivamente das condições externas, o orgânico depende de si mesmo e, por isso, exige autorregulação:

“Na verdade, o organismo é regulado, pois ele, apesar da mudança das condições externas e da infinita complexidade

\footnotetext{
140 Roux (1881), 226.

${ }^{141} \operatorname{Roux}(1881)$, p. 216.
} 
interna, conserva-se aproximadamente constante, embora a constância seja sempre apenas uma aproximação, somente existente para uma observação descuidada; e, como Darwin nos ensinou, a transformação contínua pode atingir graus bastante consideráveis." 142

A autorregulação é a essência da autoconservação ${ }^{143}$, sendo produto da acumulação de inúmeros processos de assimilação em suas variadas relações, o que forma no organismo uma "economia superior": equilíbrio entre assimilação, uso para crescimento e outras funções úteis para a conservação, desperdício e eliminação. Como a autorregulação tem limites, a autoconservação também os tem.

\section{Roux contra Kant}

Como Kant, Roux vê o organismo como uma configuração de partes que, ao contrário de um relógio, constrói a si mesma ${ }^{144}$ :

“No orgânico, os elementos de construção não estão todos previamente prontos, sendo, somente assim, juntados sucessivamente, mas, nesse caso, os elementos seguintes são sempre os produtos, os descendentes dos anteriores. Posto que os elementos já presentes não são uns iguais aos outros, um deles, favorecido por meio de qualquer propriedade particular e com seu poder de produção maior que o de outros, e,

142 Roux (1881), 70.

143 Cf. Roux (1881), 226-227.

144 Roux utiliza frequentemente a metáfora do Estado para se referir ao organismo. Por exemplo: "Pode o Estado não existir quando por toda parte os cidadãos rivalizam entre si e apenas os mais capazes chegam a influenciar o andamento geral dos acontecimentos? Tal ação recíproca [Wechselwirkung] das partes tem oportunidade de ocorrer no organismo? Essa é a questão primeira da qual tudo deve depender" (Roux (1881), 65). 
portanto, produzindo mais descendentes, possuirá uma maior participação no edifício do que os outros." 145

Roux coloca sua ênfase na diferença empírica que já existe entre as menores partes do organismo: as moléculas e as células. O biólogo proclama:

"A desigualdade das partes tem que ser o fundamento da luta das partes: dela resulta a luta em consequência do crescimento e, como queremos aqui mesmo acrescentar, também já simplesmente em consequência do metabolismo."146

Essa diferença provoca uma disputa por recursos de sobrevivência: por nutrição (Ernährung) e espaço, a luta produz unicamente por ela mesma as proporções e as funções necessárias para o organismo. Caso isso não ocorra, o organismo não se forma147.

O biólogo alemão não rejeita a noção de finalidade nos processos vitais, porém sua concepção não considera um princípio pré-existente ou transcendental para justificar a unidade do organismo ${ }^{148}$. Sua

145 Roux (1881), 67-68.

146 Roux (1881), 69; grifos no original.

147 Cf. Roux (1881), 109. “Alguns achariam o título deste capítulo e do livro estranhos [A Luta das Partes no Organismo], já que ele indica que uma luta entre as partes tem lugar internamente nos organismos animais, que existe um conflito entre indivíduos onde tudo é tão primorosamente ordenado, onde as partes mais distintas estão tão excelentemente arranjadas umas às outras e coordenadas em um conjunto perfeito, onde, portanto, tudo ocorre segundo leis fixas. E como poderia um conjunto persistir quando suas partes estão em conflito uma com as outras? / / No entanto, isso é assim. Não há no organismo, como se verá, total tranquilidade para além das partes e umas com as outras, nem na fase de saúde nem, mais ainda, na doença. No último caso, na verdade, a representação de uma discórdia interior das partes é corrente, sendo que nós temos diariamente diante de nossos olhos os seus efeitos deletérios" (Roux (1881), 64).

148 Há uma edição de A Luta das Partes em 1895. Nota-se, comparando-se os dois títulos, uma preocupação em acrescentar termos associados à seleção natural de Darwin no segundo texto. No segundo título, a palavra Zweckmässigkeit é alterada para Zweckmässigen, que é um adjetivo substantivado, com o acréscimo de aspas e do adjetivo "pretensa" (cf. Roux (1881) e (1895)). 
Zweckmässigkeit é construída pela própria dinâmica dos acontecimentos biológicos, o que faz com que ela seja mutável de acordo com as condições internas e externas. A conformidade a fins, para Roux, é resultado de processos mecânicos e aleatórios. A teleologia não é primeira, mas resultante das relações mecânicas (físico-químicas) e, ao mesmo tempo, da seleção natural de Darwin ${ }^{149}$. Assim, não há, na verdade, uma unidade rígida nos seres vivos:

"deve-se mencionar que, até mesmo nos organismos superiores, a centralização do conjunto de modo algum é tão perfeita, como ainda frequentemente se imagina, e também que a centralização não se produz de modo que as partes só possam existir no organismo ao qual elas pertencem e somente ocupar sua posição normal, e, portanto, de modo que a dependência seja perfeita, que as partes somente possam viver como parte de um conjunto solidamente normatizado."150

A unidade do organismo é resultante de um conflito incontornável entre as suas partes, ou ainda, da independência dessas partes.

\footnotetext{
1881: Der Kampf der Theile im Organismus: ein Beitrag zur Vervollständigung der mechanischen Zweckmässigkeitlehre. (A luta das partes no organismo: uma contribuição ao complemento da doutrina mecânica da conformidade a fins)

1895: Der züchtende Kampf der Theile oder die "Theilauslese" im Organismus. Zugleich eine Theorie der "functionellen Anpassung". Ein Beitrag zur Vervollständigung der Lehre von der mechanischen Entstehung des sogenannten "Zweckmässigen". (A luta seletiva das partes ou a "seleção das partes" no organismo. Simultaneamente uma teoria da "adaptação funcional". Uma contribuição ao complemento da doutrina da formação mecânica da pretensa "conformidade a fins")

149 "aquela parte que, devido ao alimento disponível ou por qualquer outra razão, for menos competente, ou seja, menos rápida ou menos perfeita para poder se regenerar, logo estará em desvantagem considerável em relação a outras partes mais favorecidas" (Roux (1881), 69). A definição de Darwin para a seleção natural é a seguinte: "Chamo de Seleção Natural a preservação de variações favoráveis e a rejeição de variações desfavoráveis" (Darwin (1985), 131). Essas variações são aleatórias, e o seu acúmulo promove a diferenciação das espécies. A seleção natural, ao lado da luta pela existência, é um conceito central no pensamento darwiniano.
}

150 Roux (1881), 65. 
O biólogo alemão, portanto, propõe a autonomia relativa das partes, o que significa que a utilidade de cada parte para o conjunto não depende da intenção de cada uma, ou seja, as partes vivem apenas para a sua própria conservação. A conservação da totalidade não é uma finalidade de cada parte:

"A utilidade desses processos [dos processos das partes] para o todo, no entanto, não é intenção $[$ Absicht $]$ das partes. A parte vive somente para sua própria conservação, e o que acontece de útil para o todo é somente devido ao fato de que apenas essas qualidades [Eigenschaften] poderiam permanecer e ainda permanecem, enquanto milhões de outras que surgiram e que, não sendo úteis ao todo, prejudicaram-no, e, com isso, o conjunto e as próprias partes tiveram que ser eliminadas." 151

Os indivíduos, ou seja, as unidades orgânicas, representam apenas casos particulares de combinações do que é capaz de se conservar na luta das partes. Contudo, as partes dependem da luta pela existência entre indivíduos, pois o que sobrevive à luta das partes, mas não está adaptada à sobrevivência do indivíduo na luta pela existência, é eliminado ${ }^{152}$. Eis a aplicação da seleção natural.

A Zweckmässigkeit, para Roux, ocorre em dois níveis: internamente no organismo e na luta pela existência entre os indivíduos. Este segundo aspecto teria sido explicado por Darwin, mas não o primeiro. Faltou ao biólogo inglês explicar a adaptação funcional, a finalidade interna: a luta das partes produz uma conformidade a fins interna enquanto a luta pela existência entre indivíduos produz uma conformidade a fins dirigida ao exterior. A adaptação funcional é o processo que suporta a capacidade de autoformação direta de conformidades a fins

151 Roux (1881), p. 219-220.

152 Cf. Roux (1881), 108. 
no organismo. O desenvolvimento do organismo, seja do indivíduo (ontogênese), seja da espécie (evolução), se dá por meio do surgimento de conformidades a fins por processos mecânicos e seleção natural, marcados por variações aleatórias ${ }^{153}$.

Os mecanismos de autorregulação, que são respostas orgânicas às condições exteriores, também são conforme a fins, e a ação reflexa tem esse caráter de forma mais marcante: "A ação reflexa é [...] um mecanismo de autorregulação da mais alta conformidade a fins [höchst zweckmässiger]"154, pois está adaptada às circunstâncias exteriores, não desperdiçando recursos. A ação que ocorre independente das circunstâncias exteriores, o automatismo (Automatie), só é útil quando o ambiente é constante, o que é extremamente raro. Os organismos não possuem uma autorregulação predeterminada, mas que se adapta a cada situação por adaptação funcional, possibilitando a ontogênese e a evolução inerente dos seres vivos ${ }^{155}$.

\section{Considerações finais: há necessidade de um princípio para a unidade orgânica?}

O filósofo neokantiano alemão Ernst Cassirer (Escola de Marburg) recoloca Roux no centro do importante debate de caráter epistemológico, iniciado por Kant e no qual o biólogo busca uma resposta estritamente mecanicista: o que é causa em biologia e qual o estatuto do conhecimento biológico ${ }^{156}$. Roux, ao contrário de Haeckel, não considerava que Darwin havia descoberto as verdadeiras causas ativas do mundo orgânico. Assim como Wilhelm His e Alexander Goette, o

\footnotetext{
153 Cf. Roux (1881), 236-238.

154 Roux (1881), 221.

155 Cf. Roux (1881), 229.

156 Cf. Cassirer (1993), 218-221 e 227-235.
} 
biólogo alemão não aceitava o princípio filogenético de Haeckel como suficiente para uma explicação causal. Não bastava o uso de métodos históricos, havia a necessidade de métodos analíticos e fisiológicos: devia-se realizar a análise separada das condições simples antes de entender como o fenômeno funcionava em seu conjunto. Isso, segundo Roux, transformaria a biologia de uma disciplina puramente descritiva em ciência causal. Além disso, seria desfeita a confusão darwiniana entre o problema do "por que" e o problema do "que". Essa posição, no entanto, não significava a rejeição da descrição, do método histórico, já que o próprio Roux realizava o que ele chamava de experimento puramente descritivo, como o que ele executava com as células-ovo de rãs ${ }^{157}$. A mecânica do desenvolvimento, nesse contexto, propõe-se como uma ciência das causas, das forças singulares e de suas relações, quer entender o movimento do organismo como um todo a partir do movimento das partes.

Roux, portanto, ao contrário de Kant, pretendia dar à biologia o mesmo caráter da física. Para que o método analítico da física fosse aplicado na biologia era necessário converter o organismo em um sistema de forças mecânicas, ou seja, tal como os corpos inorgânicos, em conjuntos de simples pontos de massa, absolutamente uniformes, o que permitiria um tratamento matemático dos seres vivos. Porém, segundo Cassirer, não é possível fazer isso nos fenômenos orgânicos, e Roux, ao lado dos fatores externos, teve que considerar o que ele chamou de "fatores de determinação"158. O embriologista alemão,

${ }^{157}$ Não se pode esquecer, contudo, que os experimentos embrionários de Roux não eram simplesmente descritivos, pois ele intervinha diretamente no desenvolvimento embrionário, eliminando células e experimentando os efeitos de vários fatores.

158 Em relação aos fatores de determinação, apresentados em Sobre a Visão de Mundo Causal e Condicional (1913), Roux parece ter se inspirado nas ideias de Weismann, as quais possuem um contexto pré-formacionista e bastante diferente do dele. Para Weismann, o plasma germinativo, estrutura inicial da embriogênese, seria constituído por vários ids, que continham todas as possibilidades do novo organismo. Cada id teria, ao longo da história da vida, sofrido seu próprio processo de desenvolvimento. $\mathrm{O}$ id seria composto, por sua vez, por unidades menores, os determinantes, arranjados conforme 
ao tentar estabelecer as relações entre fatores externos e internos, sai do âmbito estrito de uma doutrina mecanicista, precisando até mesmo de uma linguagem distinta. Determina-se, portanto, que o mecanicismo não é suficiente para dar conta do conhecimento biológico. No caso de Roux, a função passa a ter relevância, e dez funções ou auto-ergasias são definidas (em A Mecânica do Desenvolvimento (1905) e A Essência da Vida (1915)): mudança, excreção, absorção, assimilação, crescimento, movimento, multiplicação, transmissão de caracteres, adaptação e conservação. Essas auto-ergasias são observáveis e caracterizam o ser vivo, definem um meio interior e estão estreitamente ligadas à autorregulação estrutural.

Concordamos com Cassirer no problema da distinção entre o meio interno e o meio externo. Para uma doutrina mecanicista, poder-se-ia perguntar: existe, no terreno da observação, possibilidade de distinguir entre o interior e o exterior, entre as funções que o organismo realiza e os efeitos de causas exteriores? Como distinguir o que é externo do que é interno, se todos os elementos e forças estão em relação entre si? Essa distinção está no âmbito da ciência natural ou é metafísica? Acreditamos que esse problema não existe para o princípio de conformidade a fins de Kant. Para M. Verworn (A Investigação da Vida, Die Erforschung des Lebens, 1907, e Visão de Mundo Causal e Condicional, Kausale und konditionale Weltanschauung, 1912), Roux rompe com seu próprio programa mecanicista já de início, pois não definiu claramente o que era um pensamento causal ${ }^{159}$. Se o tivesse feito, a distinção entre causas externas e internas não se sustentaria, já que ela não é resultado empírico, mas postulação metafísica. A causa, para Verworn, deve ser um conceito de condição e não de explicação: devemos buscar, para entender como algo ocorre, suas condições, que são várias e igualmente

uma ordem pré-determinada. Haveria um determinante para cada parte do organismo adulto, e os bióforos seriam partículas emitidas por eles. Essas partículas atingiriam o citoplasma para dirigir as atividades vitais (cf. Pinto-Correia (1999), 378-379).

159 Cf. Cassirer (1993), 234. 
necessárias, e não suas causas. Roux responde energicamente a essas críticas em Sobre a Visão de Mundo Causal e Condicional (Über kausale und konditionale Weltanschauung, 1913): é necessário distinguir duas classes de fatores, nem todos eles são equivalentes, pois, se todos participam, não participam com o mesmo valor, uns são determinantes, outros não. Autores como J. Schaxel e Hans Driesch apontaram que a ênfase na autorregulação provoca a dissolução da mecânica do desenvolvimento ${ }^{160}$. Este último insiste que mecânica e desenvolvimento são noções incompatíveis. De qualquer forma, parece-nos que a falta de um critério de demarcação entre os meios interno e externo, em última instância, a falta do que determina a unidade do organismo, abre o campo para princípios pré-existentes ou mesmo para propostas vitalistas.

A independência das partes defendida por Roux faz com que a conformidade a fins esteja presente já nas menores partes e não em um princípio que seja responsável pela unidade do organismo. Além disso, essa conformidade a fins tem um caráter puramente mecânico, isto é, cego, não sendo nem transcendente (no sentido metafísico) nem transcendental (no sentido kantiano). Embora o desenvolvimento dos organismos (embrionário, pós-embrionário e evolutivo) e a transmissão hereditária se deem por leis imutáveis, essas leis não agem de modo constante devido às relações tanto internas como externas que a todo momento desafiam os seres vivos ${ }^{161}$. Nesse contexto, o movimento, o vir-a-ser, tem um papel extremamente importante no pensamento do biólogo alemão. Se a proposta de Roux não conseguiu ser uma alternativa adequada à conformidade a fins kantiana, nós consideramos que o interesse pelo pensamento de Roux se justifica, ao menos, pelo conhecimento de um caminho apontado entre vários outros no intenso debate que se seguiu após a publicação de Crítica da Faculdade do Juízo, no âmbito da filosofia, e de Origem das Espécies, no âmbito

160 Cf. Cassirer (1993), 235.

161 Cf. Roux (1881), 106-107. 
do pensamento científico sobre os seres vivos, um caminho que segue pela crítica ao determinismo genético extremado e que considera que o que deve ser explicado é a diferença e não a semelhança. Foram esses aspectos que atraíram Nietzsche para a leitura de A Luta das Partes.

Agradeço ao Prof. Luciano Carlos Utteich pelas preciosas indicações acerca da Crítica da Faculdade do Juízo.

\section{Bibliografia}

CASSIRER, Ernst (1993): El problema del conocimiento em la filosofía y em la ciencia modernas IV: de la muerte de Hegel a nuestros dias (1832-1932). Traducción de W. Roces. México, Fondo de Cultura Económica.

CORDEIRO, Renato V. (2010): “A Antinomia da Faculdade de Julgar Teleológica”. In: Analytica 14(1), pp. 139-171.

CORDEIRO, Renato V. (2012): “O Apêndice à Dialética Transcendental e o Aparente Conflito entre Mecanicismo e Finalidade na Antinomia da Faculdade de Julgar Teleológica". In: Marques, Ubirajara R. de A. (org.): Kant e a Biologia. São Paulo, Barcarolla, pp. 129-151.

DARWIN, Charles R. (1985): The Origin of Species. 17th edition. London, Penguin Books. (Conforme primeira edição de 1859)

FREZZATTI Jr., Wilson Antonio (2001): Nietzsche contra Darwin. São Paulo/Ijuí, Discurso/ Unijuí.

HAECKEL, Ernst H. (1904): Les merveilles de la vie-Études de philosophie biologique. Paris, Schleicher frères.

HEAMS, Thomas (2012): "Préface: La lutte des parties dans l'organisme, ou l'impasse visionnaire". In: Roux, Wilhelm: La lutte des parties dans l'organisme. Traducteurs: L. Cohort, S. Danizet-Bechet, A.-L. Pasco-Saligny et C. Thébault. Paris, Matériologiques, pp. 11-25.

KANT, Immanuel (1999): Crítica da Razão Pura. Tradução de V. Rohden e U. B. Moosburguer. São Paulo, Nova Cultural.

KANT, Immanuel (2008): Crítica da Faculdade do Juízo. 2ª. ed. Tradução de V. Rohden e A. Marques. Rio de Janeiro, Forense Universitária.

LAMARCK, Jean-Baptiste (1994): Philosophie zoologique. Paris, Flammarion.

LENOIR, Timothy (1982): The Strategy of Life: Teleology and Mechanics in Nineteenth Century German Biology. Dordrecht, D. Reidel.

LEQUAN, Mai (2000): La chimie selon Kant. Paris, PUF.

MARQUES, Ubirajara R. de A. (2012): “Considerações sobre a Epigênese em Kant". In: Marques, Ubirajara R. de A. (org.): Kant e a Biologia. São Paulo, Barcarolla, pp. 331-364. 
MAYR, Ernst (1998): Desenvolvimento do Pensamento Biológico: Diversidade, Evolução e Herança. Tradução: I. Martinazzo. Brasília, Editora Universidade de Brasília.

MENDELSOHN, Everett (1964) : “The Biological Sciences in the Nineteenth Century: Some Problems and Sources". In: History of Science 3, pp. 39-59.

MÜLLER-LAUTER, Wolfgang (1998) : “L'organisme comme lutte intérieure: l'influence de Wilhelm Roux sur Friedrich Nietzsche". In: Müller-Lauter, Wolfgang: Nietzsche: physiologie de la volonté de puissance. Paris, Allia, pp. 111-164.

PINTO-CORREIA, Clara (1999): O Ovário de Eva: A Origem da Vida. Tradução: S. Coutinho. Rio de Janeiro, Campus.

ROUX, Wilhelm (1881): Der Kampf der Theile im Organismus: ein Beitrag zur Vervollständigung der mechanischen Zweckmässigkeitlehre. Leipzig, Verlag von Wilhelm Engelmann.

ROUX, Wilhelm (1895): “Der züchtende Kampf der Theile oder die 'Theilauslese' im Organismus. Zugleich eine Theorie der 'functionellen Anpassung'. Ein Beitrag zur Vervollständigung der Lehre von der mechanischen Entstehung des sogenannten 'Zweckmässigen'". In: Roux, Wilhelm: Gesammelte Abhandlungen über Entwickelungsmechanik der Organismen. Erster Band: Abhandling I - XII, vorwiegend über functionelle Anpassung. Leipzig, Verlag von Wilhelm Engelmann, pp. 135-437.

SANTOS, Leonel R. dos. (2012): "A Formação do Pensamento Biológico de Kant". In: Marques, Ubirajara R. de A. (org.): Kant e a Biologia. São Paulo, Barcarolla, pp. 17-81. 
